\title{
Application of Geo-spatial Techniques in Soil Suitability analysis for Major Crops of Nizamabad District, Telangana
}

\author{
Dhanashree Pable, Saumen Saha, Ravindra Kulkarni*, A.W.M. Joseph and V.S. Arya \\ Soil and Land Use Survey of India, Nagpur, Maharashtra - 440013, India
}

\begin{abstract}
The objective of land use planning is to make decisions on land use in such a way that the natural resources are put to the most beneficial use for man, while ensuring sustainability and conserving ecosystem. Each plant species requires specific soil-site conditions for its optimum growth. For rationalizing land use, the soil-site suitability for different crops needs to be determined. In the present investigation, soil-site suitability evaluation was carried out for paddy, maize, turmeric and mango crops of Nizamabad district of Telangana. The spatial database was generated using IRS-1D LISS-III satellite data. The spatial database and soil properties were integrated and analysed for the evaluation of suitability class of these crops using FAO guidelines in Geographical Information system (GIS) environment. The results indicated that out of total geographical area of 7,06,084 ha of the district, 53.5 per cent area was moderately suitable to paddy, 50.6 per cent area was marginally suitable for maize, 13.1 per cent was moderately suitable for turmeric while 40.4 per cent of area was marginally suitable for mango.
\end{abstract}

Keywords: GIS, land use, LISS-III, soil suitability, Nizamabad

\section{Introduction}

Soil-site suitability studies provide information on the choice of crops to be grown on best-suited soil unit for maximizing crop production per unit of land, labour and inputs. The land suitability for defined use and the impact of the use on environment is determined by land conditions and land qualities. The sustainable land use depends on soil resilience which is a balance between soil restorative and soil degradation processes. Ecologically, every factor of environment exerts directly or indirectly a specific effect on growth and development of the plant. However, it varies from habitat to habitat and determines the suitability of a plant to any particular environment.

Extensive and reliable information on natural resource, their spatial distribution, location extent and their interaction with socio-economic fabric of the area are pre-requisite for efficient and effective resource management. Mapping of soil resources through conventional method is very difficult considering the topographical features, submerged coastal line coupled with inaccessible terrain condition. Remote Sensing (RS) Technology has been found to be a valuable tool for mapping, monitoring and management of soil resources by virtue of its synoptic view and high resolution.

Nizamabad district of Telangana produces $5,15,226$ MT of paddy followed by 1,40,609 MT of maize. Nizamabad region of Telangana is a major contributor to India's turmeric production, accounting for about 25 per cent of the total production with an average of 6.59 tons ha ${ }^{-1}$ (Anonymous 2013). Turmeric is mainly inter-cropped with maize in this region. Therefore, the present study was undertaken to carry out soil-site suitability for different crops using geospatial techniques in Nizamabad district of Telangana.

\section{Materials and Methods}

Study Area

Nizamabad district lies between $18^{\circ} 05^{\prime}$ to $19^{\circ} 05^{\prime}$ of North latitude and 77004' to $78037^{\prime}$ of East

* Corresponding author (Email : ssonagpur-slusi@nic.in) 


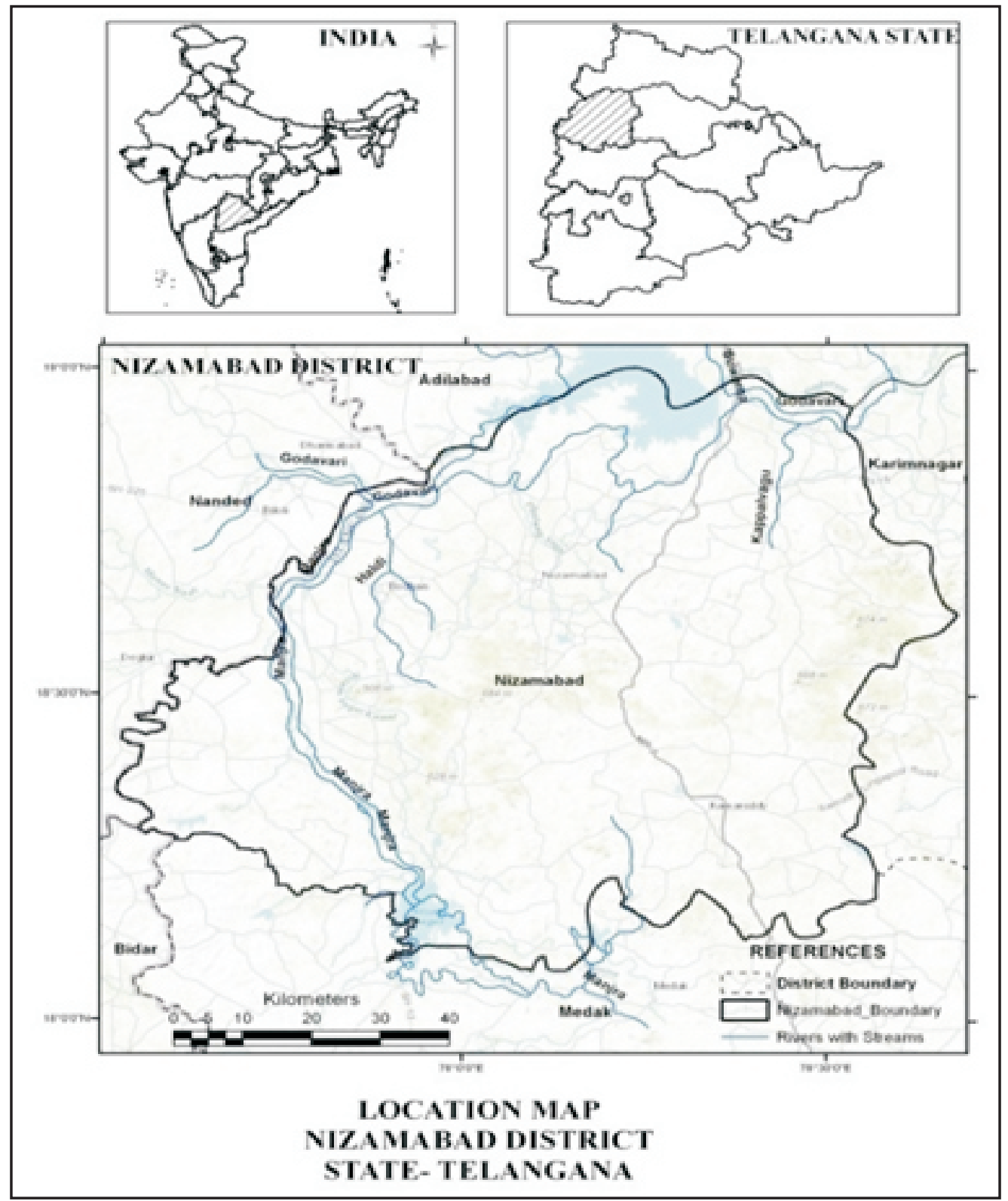

Fig. 1. Location map of study area

longitude (Fig. 1) and covered by Survey of India (SOI) toposheet nos. $56 \mathrm{~F} / 10,11,12,13,14,15$ and 16 and 56 $\mathrm{J} / 1,2,3,4,5,6,8,9,10,11$ and 12 on $1: 50,000$ scale. The district is bounded by Adilabad district on the north, Karimnagar district on the east, Medak district on the south and Nanded district of Maharashtra state and Bidar district of Karnataka state on the West. It falls in the Agro-Climatic zone 10 (Southern Plateau \& Hills Region). The total geographical area of Nizamabad district is 7,06,084 ha out of which $2,22,600(31.5 \%)$ is under forest and $71,794(10.2 \%)$ is under different miscellaneous uses.
Nizamabad is situated on the Deccan Plateau, one of the oldest geological formations of the country. The granitic landscape varies with landforms such as lower pediplains, upper pediplains and undifferentiated hill side slope followed by a physiographic unit of alluvial plains. The hill side slopes are generally very steep to steep. The plateau and alluvial plains vary from very gently to gently sloping regions. The district falls under Godavari river basin. The two tributaries Manjira and Maneru join the Godavari. The Manjira flows from south-east to north-west and then towards North, takes 
an easterly turn and then flows in N-NE direction before joining the Godavari at Kadakurthi. The Maneru river flows from Kamareddy towards south-east in the district. The drainage predominantly forms dendritic pattern which is governed by lithology of the area in the absence of structural control. Granitic and basaltic terrains mainly exhibit this type of pattern, while, the rare parallel to sub-parallel drainage pattern locally exhibited in alluvial areas.

\section{Soil mapping}

The soil resource inventory was generated through soil resource mapping of Nizamabad district during 2012-13. The Indian Remote Sensing Satellite IRS-ID LISS-III and geocoded False Colour Composite (FCC) on 1:50,000 scale of the month of February and April of 2006 were used for image interpretation. Base map was prepared using the Survey of India (SOI) toposheets (1:50,000 scale). Toposheet-wise tracing of permanent features like rivers, drainage lines, roads, canals, habitations etc. was done on transparent drafting sheets for the whole district. Landscape boundaries were drawn on the base map using SOI toposheet. Slope map was prepared from SOI toposheet on 1:50,000 scale from contour information. A mosaic of imageries was prepared to delineate major landscape. The variation of image elements e.g. tone, texture, size, shape, pattern, location etc. in each landscape was further divided into different major physiographic units. These discernable variations were in terms of geology, physiography, slope and land use/land cover conditions. Areas were selected for ground truthing in order to establish correlation between spectral signature of the image with soil and its associated land features. Soil profiles were taken in different landscape and physiographic positions to understand the physiography-soil relationship. Soils morphological properties were recorded through soil profile examination. Soil samples were collected from soil profiles for detailed physicochemical analysis. Soil series and their association were mapped as mapping units.

\section{Land Evaluation}

The parametric approach was used to evaluate land for its suitability as per FAO (1976) guidelines and later modified by Sys (1993). This approach is based on the comparison of the qualities of different land units with the requirements of actual or potential land use. The soil parameters selected were soil depth, texture, pH, ESP (Exchangeable Sodium Percentage) and slope. The selected soil properties were compared with the ideal values of crop requirements as per suitability criteria developed by Naidu et al. (2006). The simple limitation method was used to categorise suitability classes and graded into S1 (Highly suitable), S2 (moderately suitable), S3 (marginally suitable) and N (Not suitable). Each characteristic was considered as a thematic layer in the map using GIS environment. Final composite map was generated for paddy, maize, mango and turmeric based on suability classes for each crop.

\section{Results and Discussion}

\section{Soil properties}

In the present study area, granitic, basaltic and alluvium type of landscapes were observed. The granitic landscape $(80.6 \%$ of total area) of the district is characterized by three physiographic units viz., hills, foot hill slopes and pediplains. Shallow to very shallow soils were observed at 33-50 per cent slope, 10-25 per cent slope, where the $\mathrm{pH}$ ranged from 6.5-6.8. On upper pediplain at 3-10 per cent slope, the soils were slightly acidic in nature and very shallow in depth. On lower pediplains at $0-5$ per cent slope, the soils are more than $100 \mathrm{~cm}$ deep with alkaline $\mathrm{pH}(8-8.4)$. The basaltic landscape ( $9.1 \%$ out of total area) of Nizamabad district having 0-3 per cent slope has shallow to moderately deep soils under open scrub and agriculture land use. These soils have sandy loam to clay loam texture and $\mathrm{pH}$ ranged from 6.3 to 7.0. The district has little area under alluvium landscape ( $0.13 \%$ area) having very deep soils on 0-3 per cent slope.

\section{Soil taxonomy}

Majority of soils have developed over granite $(80.6 \%)$ followed by basaltic parent material $(9.1 \%)$ and alluvium $(0.13 \%)$. Soils of the study area were classified into four soil orders, namely, Entisols, Inceptisols, 
Table 1. Soil suitability for different crops

\begin{tabular}{ccccc}
\hline Soil Suitability & Paddy (ha) & Maize(ha) & Mango(ha) & Turmeric(ha) \\
\hline S2 & $3,77,624(53.5)^{*}$ & $3,57,346(50.6)^{*}$ & - & $92,289(13.1)^{*}$ \\
S3 & $19,451(2.6)^{*}$ & $39,729(5.6)^{*}$ & $2,85,335(40.4)^{*}$ & $3,04,786(43.2)^{*}$ \\
N & $14,615(2.1)^{*}$ & $14,615(2.1)^{*}$ & $1,26,355(17.9)^{*}$ & $14,615(2.1)^{*}$ \\
\hline
\end{tabular}

*value in the parenthesis indicates area in percentage

Alfisol and Vertisols (NRCS 2010). The Orthents with ustic moisture regime, with no lithic contact within 50 $\mathrm{cm}$ of mineral soil surface is classified as Typic Ustorthents. Soils that have lithic contact within $50 \mathrm{~cm}$ of the mineral soil surface are classified as Lithic Ustorthents. The soils having ustic moisture regime and hence placed in Ustepts suborder, Haplustepts great group and subgroup Typic Haplustepts. Few soils have been classified as Typic Haplustalfs. Soils that have a densic, lithic, paralithic contact or a duripan within 100 $\mathrm{cm}$ of the mineral soil surface were classified as Leptic Haplusterts and others are classified as Typic Haplusterts.

\section{Suitability evaluation}

Out of total geographical area of the district, 58.3 per cent area was under cultivation, 31.5 per cent area was under forest and remaining 10.2 per cent area was under road, river, nala and habitation.

Paddy is a tropical plant and requires high temperature and high humidity for its successful growth. The mean temperature should range from $21^{\circ} \mathrm{C}$ to $35^{\circ} \mathrm{C}$. The average annual rainfall required for rice is about $110-150 \mathrm{~cm}$. It can be grown on a variety of soils including clay, clay loam and loams and can tolerate acidic as well as alkaline soils. However, deep fertile clayey or loamy soils which can easily be puddled and develop cracks on drying are considered ideal for raising this crop.

The suitability evaluation (Table 1; Fig. 2) indicated that 53.5 per cent area was moderately suitable (S2), 2.8 per cent area was marginally suitable

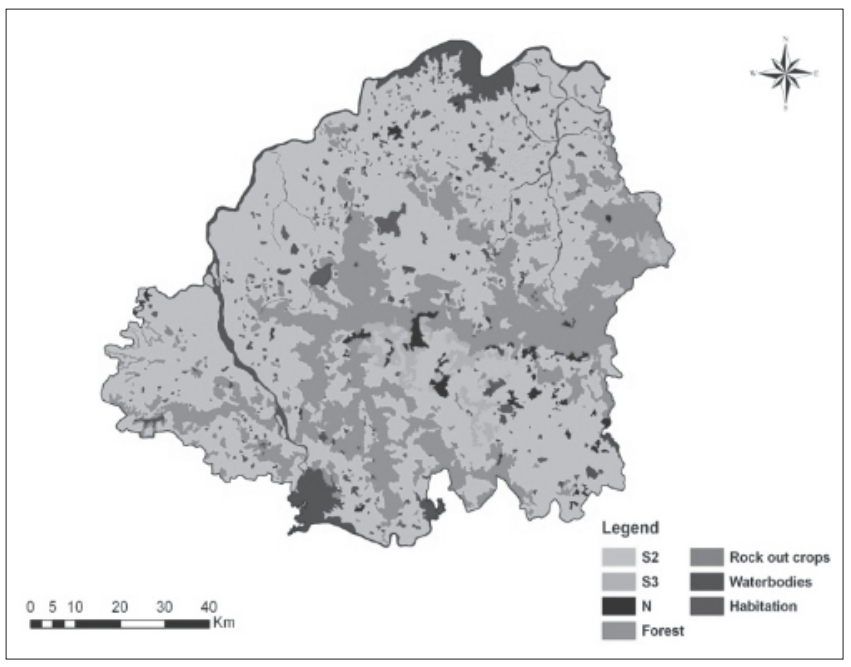

Fig. 2. Soil-site suitability map for paddy

(S3) and 2.1 per cent area was not suitable $(\mathrm{N})$ for paddy cultivation.

Maize is one of the most versatile crops that have wider adaptability under varied agro-climatic conditions. Maize can be grown successfully in variety of soils ranging from sandy loam to clay loam. However, soils with good organic matter content with neutral $\mathrm{pH}$ are considered good for higher productivity. Being a sensitive crop to moisture stress, excess soil moisture and salinity stresses, it is desirable to avoid low -lying fields having poor drainage and also the fields having higher salinity.

The suitability evaluation (Table 1) indicated that 50.6 per cent area was moderately suitable (S2), 5.6 per cent was marginally suitable (S3) and 2.1 per cent area was not suitable $(\mathrm{N})$ for maize. Most of the area (Fig. 3) was under moderately suitable categories are well drained with moderate erosion. 


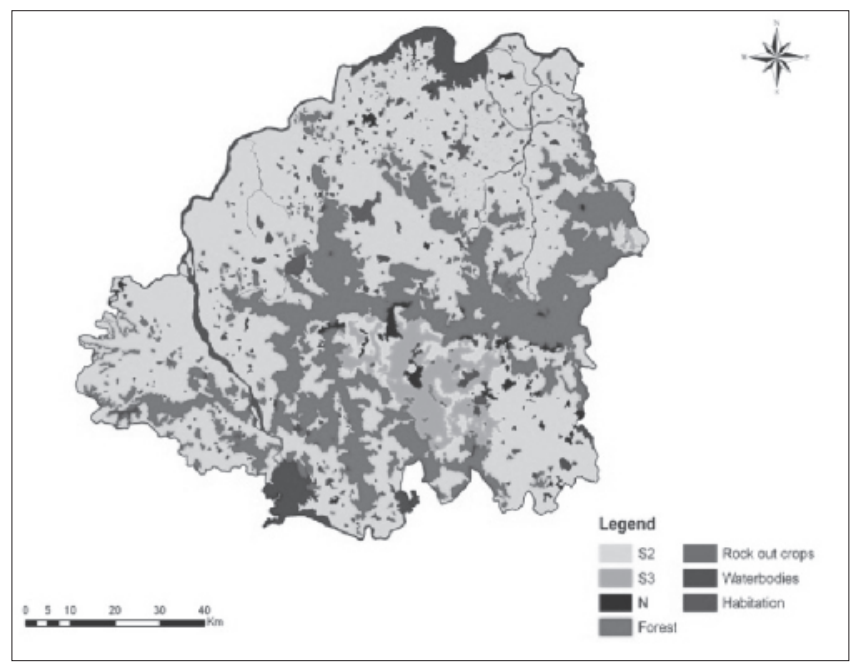

Fig. 3. Soil-site suitability for maize

Mango is better suited to alluvial soils with good amount of organic matter and soil $\mathrm{pH}$ between 6.5 to 7.5. Poorly drained soils should be avoided. It does not perform well in soils with $\mathrm{pH}$ more than 7.8. Mango is very well adapted to tropical and sub-tropical climate. The study indicated that 40.4 per cent area was marginally suitable (S3) to mango and 17.9 per cent area was not suitable for mango (N) (Table 1 and Fig. 4.)

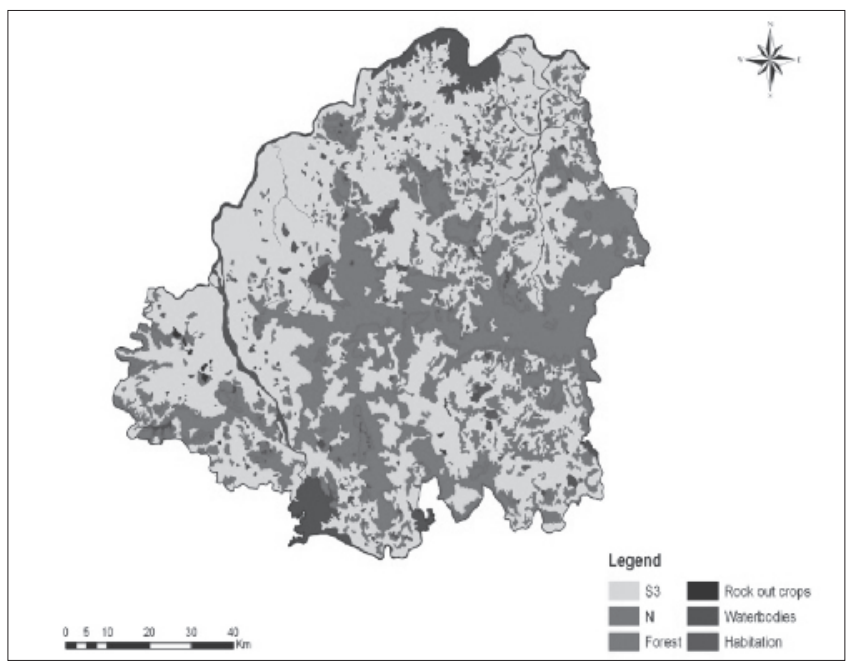

Fig. 4. Soil-site suitability for Mango

Turmeric requires a warm and humid climate. Though turmeric thrives in different types of soils ranging from light black loam, red soils with loam and clay loams having natural drainage and irrigation facilities are the best. Turmeric cannot stand water stagnation or alkalinity. It requires well drained, loose and friable loamy or alluvial soil. Heavy black or clayey soils are unsuitable as rhizome development is not proper. It was observed that 13.1 per cent area was moderately suitable (S2), 43.2 per cent area was marginally suitable (S3) and 2.1 were not suitable $(\mathrm{N})$ for growing turmeric (Table $1 \&$ Fig. 5). The areas with severe limitations like strongly to moderately steep slope and moderate to severe soil erosion are not suitable (2.1 per cent) for growing turmeric.

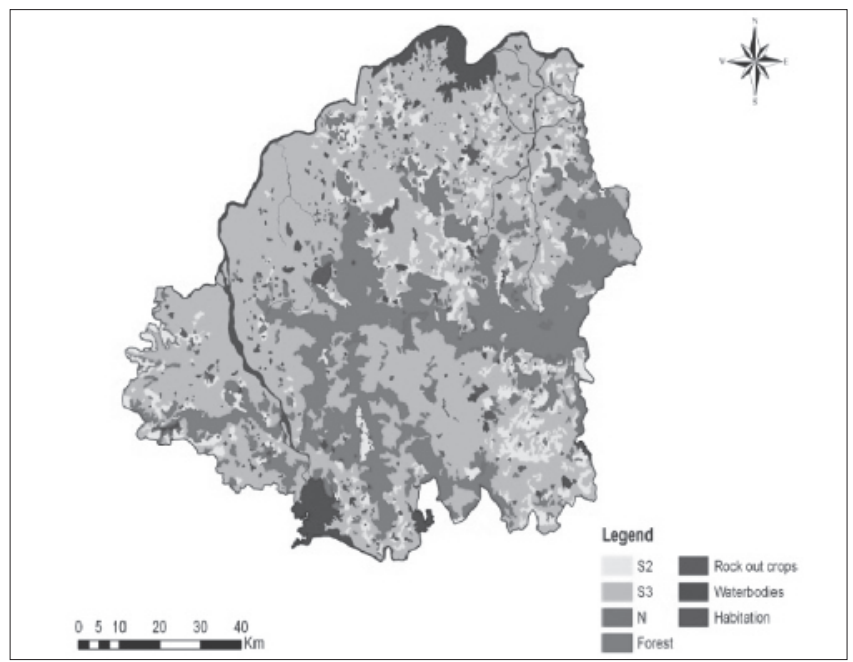

Fig. 5. Soil site suitability for Turmeric

\section{Conclusion}

The study indicated that 53.5 per cent area was moderately suitable for paddy, 50.6 per cent area was moderately suitable for maize, 13.1 per cent was moderately suitable for turmeric. About 43.2 and 40.4 per cent of area was marginally suitable for growing turmeric and mango. Area with steep slop and server erosion covering 2.1 per cent of TGA was not suitable for growing arable crops and suggested for agro-forestry and agri-horticulture interventions.

\section{References}

Anonymous (2013). District report from Department of Agriculture, Nizamabad.

FAO (1976). Food and Agriculture Organisation. A Framework for Land Evaluation Soils Bulletin No. 32, FAO, Rome. 
Naidu L.G.K., Ramamurthy V., Challa O., Hegde Rajendra and Krishnan P. (2006). Manual soil-site suitability criteria for major crops.Technical.Bulletin.No. 129, NBSS \& LUP, Nagpur India, pp 118.
NRCS (2010). Keys to Soil Taxonomy. Eleventh Edition United State Department of Agriculture. Natural Resources Conservation Service.

Sys C. 1993. Land Evaluation Part II. State university of Ghent, The Netherlands. 